\title{
Design of heat exchanger for cooling fluid used on magnetic induction welder
}

\author{
Ekadewi A. Handoyo ${ }^{1}$, Lita Puspasari ${ }^{2}$ \\ ${ }^{1}$ Mechanical Engineering Department - Petra Christian University \\ Jl. Siwalankerto 121-131, Surabaya 60236. Indonesia \\ Phone: +62-31-8439040, Fax: +62-31-8417658 \\ Email korespondensi: ekadewi@ petra.ac.id
}

\begin{abstract}
Abstrak
Pengelasan induksi magnetik adalah proses umum dalam produksi pipa. Impeder yang digunakan dalam mesin las perlu didinginkan untuk menjaga suhunya di bawah $35^{\circ} \mathrm{C}$. Cairan pendingin adalah air dengan $2 \%$ cutting oil dan disebut pendingin. Itu harus memasukkan impeder pada 15oC. Laju aliran yang dibutuhkan adalah sebanyak 30 lt / mnt. Untuk memastikan suhu impeder dijaga lebih rendah dari suhu yang dibutuhkan, maka penukar panas harus dirancang untuk mendinginkan pendingin dari $40^{\circ} \mathrm{C}$ hingga $15^{\circ} \mathrm{C}$. Air chiller berpendingin udara tipe UWAP750AY3 digunakan untuk menghasilkan air dingin yang dibutuhkan oleh penukar panas. Pipa tembaga bersirip 5/8-inci digunakan sebagai tabung di penukar panas. Pendingin dibagi dalam empat tabung yang sama dari header. Untuk memenuhi area perpindahan panas yang dibutuhkan, setiap tabung akan ditekuk untuk membuat 10 lintasan (atau baris). Di akhir baris terakhir, empat aliran akan dikumpulkan di header. Kemudian, pendingin akan diedarkan ke impeder dengan suhu yang dibutuhkan. Simulasi numerik dilakukan untuk mendapatkan vektor kecepatan dan distribusi suhu aliran di dalam tabung, dan juga penurunan tekanan aliran melintasi tabung dan header. Vektor kecepatan aliran di sekitar tikungan balik, aliran masuk dan keluar menarik. Mereka memberikan pemahaman bahwa penurunan tekanan akan lebih tinggi pada aksesori semacam itu daripada pada pipa lurus. Penurunan tekanan cairan pendingin yang mengalir di dalam tabung penukar panas adalah 5143,2 Pa dari solusi analitis dan 4611,4 Pa dari simulasi numerik menggunakan Fluent. Temperatur cairan pendingin di outlet yang didapat dari simulasi numerik hampir sama dengan suhu yang dirancang, yaitu $15^{\circ} \mathrm{C}$. Jadi, simulasi numerik memperkuat desain penukar panas.
\end{abstract}

Kata kunci: penukar kalor, cairan pendingin, shell and tube.

\begin{abstract}
Magnetic induction welding is a common process in pipe production. The impeder used in the welding machine needs to be cooled to maintain its temperature below $35^{\circ} \mathrm{C}$. The cooling fluid is water with $2 \%$ cutting oil and called coolant. It should enter the impeder at $15^{\circ} \mathrm{C}$. The required flow rate is as much as $30 \mathrm{lt} / \mathrm{min}$. To ensure the impeder's temperature be kept lower than required temperature, then the heat exchanger shall be designed to cool the coolant from $40^{\circ} \mathrm{C}$ to $15^{\circ} \mathrm{C}$. Air-cooled water chiller type UWAP750AY3 is used to produce chilled water needed by the heat exchanger. The 5/8-inch-finned-copper pipes are used as tubes in the heat exchanger. The coolant is divided in four equally tubes from a header. To meet the heat transfer area needed, each tubes will be bent to make 10 passes (or rows). At the end of the last row, four flow will be gathered in a header. Then, the coolant will circulate to impeder with the required temperature. Numerical simulation was conducted to get the velocity vector and temperature distribution of flow inside the tube, and also the pressure drop of the flow across the tubes and header. Velocity vector of flow around return bend, flow in entrance and exit are interesting. They give understanding that the pressure drop will be higher in such accessories than in straight pipe. The pressure drop of coolant flowing inside tubes of heat exchanger is 5143.2 Pa from analytical solutions and 4611.4 Pa from numerical simulation using Fluent. Temperature of coolant at outlet got from numerical simulation is almost the same with the designed temperature, i.e. $15^{\circ} \mathrm{C}$. So, the numerical simulation reinforces the design of the heat exchanger.
\end{abstract}

Keywords: heat exchanger, cooling fluid, shell and tube.

\section{Introduction}

A pipe making process could be comprised of extrusion that produces seamless pipe or rolling the sheet metal and welding the joint. A welding could use a magnetic induction process. The impeder used in the welding machine needs to be cooled to maintain its temperature below $35 \mathrm{oC}$. If temperature of the impeder is more than $350 \mathrm{C}$ during welding process, the joint could be cracked or broken. Bad welded joint will harm piping production from time, material, and economic. This problem did ever happen in PT. SPINDO. To maintain the temperature of impeder stays less than $350 \mathrm{C}$, the cooling fluid shall enter the impeder at $15 \mathrm{oC}$. The cooling fluid is water with $2 \%$ 
cutting oil. The cooling fluid is called coolant with flow rate as much as $30 \mathrm{lt} / \mathrm{min}$.

The coolant coming out of impeder is cleaned to remove contaminant that might be carried in it. The fluid is ready to be sprayed into impeder whenever its temperature is as low as $15^{\circ} \mathrm{C}$. A heat exchanger is required to cool this cooling fluid. To ensure the required temperature, the heat exchanger shall be designed to cool coolant from $40^{\circ} \mathrm{C}$ to $15 \mathrm{oC}$. According to [1] plate heat exchanger in most cases give higher efficiencies Yet, plate heat exchanger has some disadvantage such as finding leakeage is difficult, bonding material between plates limits operating temperature, pressure drop caused by plate heat exchanger is higher than tube heat exchanger [2] The shell and tube heat exchanger is less expensive compared to plate type, has less pressure drop across the heat exchanger, and can be used in systems with higher operating temperature or pressure [2]. Therefore, the heat exchanger is designed in shell and tube type. Coolant will flow in the tubes which are dipped into chilled water in the shell side. The chilled water is produced by a water chiller.

\section{Metode}

The first step to do is predicting the cooling capacity needed in this heat exchanger to cool the coolant. From this cooling capacity, a commercial air-cooled water chiller is chosen. Chiller chosen is air-cooled, because it is cheaper to cool condensor with air than water for small chiller. The chiller's manufacture give some data such as chilled water produced. This flow rate data of chilled water is important in designing the heat exchanger. When the coolant flows inside tubes, it will transfer its heat to the chilled water in the shell side. The heat transfer area is predicted through some elaborate calculation. With a certain tube diameter, the length of tubes could be calculated. The length of tubes affect the dimension of heat exchanger, including its height. The maximum height in the plant is $1.5 \mathrm{~m}$.

Some data such as coolant temperature entering leaving heat exchanger and chilled water temperature entering - leaving air-cooled water chiller and the diagram block is shown in Fig. 1. These data are used in predicting and designing the heat exchanger.

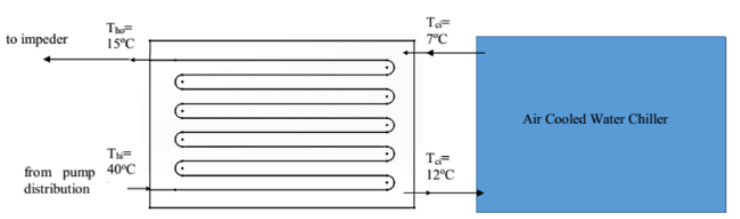

Figure 1. Coolant heat exchanger diagram with Air Cooled Water Chiller

\section{Result and Discussions}

\section{Calculation and Result of $\mathrm{HE}$ designed}

The thermal properties of water will be used for coolant, because it contains only $2 \%$ cutting oil and is basically water. The coolant transfers heat to the chilled water as much as $52 \mathrm{~kW}$. So, the air-cooled water chiller capacity needed should more than 52 $\mathrm{kW}$. From the chiller manufacture, it is found that the most suitable chiller selected is UWAP750AY3 and has $67 \mathrm{~kW}$ cooling capacity [4]. The chilled water produced by this chiller is $192 \mathrm{~L} / \mathrm{min}$. Thus, the chilled water will enter and leave the heat exchanger at $7^{\circ} \mathrm{C}$ and $12^{\circ} \mathrm{C}$, respectively.

According to Incropera and DeWitt, heat transfer will be increasing when the flow is turbulent. The flow starts to be turbulent when Reynolds number more than 2300. Yet, the flow will be fully turbulent when it pass the transition area, which is at Reynolds number $=10,000$ [3]. So, the coolant flow will be designed to have Reynolds number $=10,000$. For $5 / 8$ inch commercial copper pipe, the coolant will flow in 6 rows of pipe. A header will be used to accumulate the flow before and after distribution as shown in Fig. 2. To simplify the manufacturing and maintenance process, PT SPINDO ask that the header and the shell of heat exchanger is box shape.

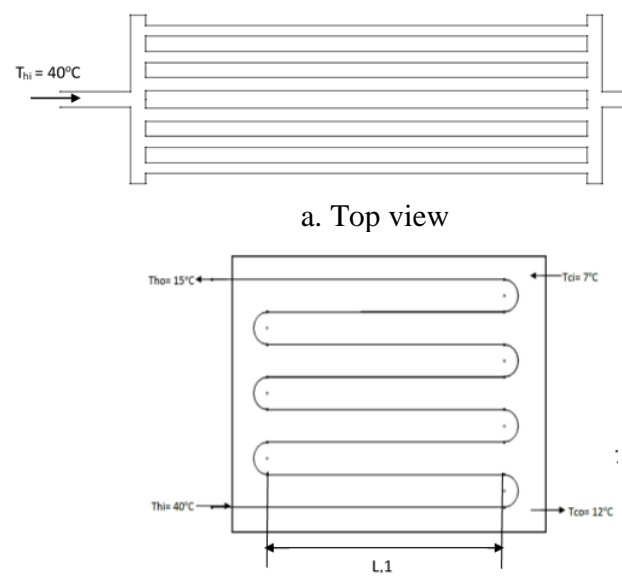

b. Side view

Figure 2. Scheme of heat exchanger straight tube without fin

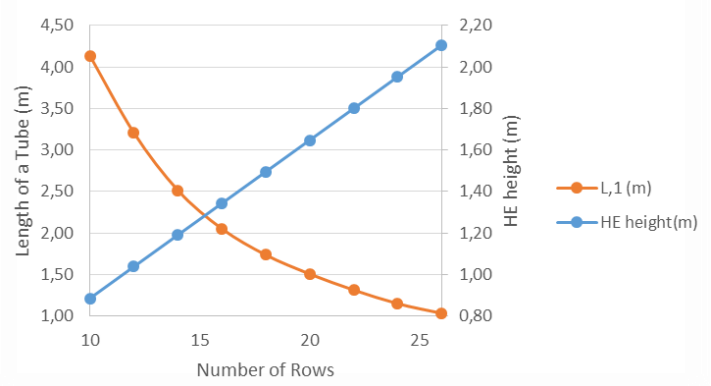

Figure 3. Some alternatives of heat exchanger straight tube without fin

Using some elaborate equations, length of each tube needed is $158,8 \mathrm{~m}$ for straight pipes. To meet this length, the pipe will be bent and make some passes. The radius of bending a pipe should be more than 4 
times outer diameter of tube or in this case it is more than $0,0762 \mathrm{~m}$. Some calculation was conducted to observe the affect of number of pass (or rows) to a pipe's length and the heat exchanger's height. The result is shown in Fig. 3. The term "L, 1 (m)" means length of each tube in unit meter and term "HE height (m)" means height of heat exchanger in unit meter. From Fig. 3, it is shown that when HE use more number of rows, the pipe will be shorter but HE height will be larger. For example, when the HE use ten number of rows, then each pipe length should be 4.14 $\mathrm{m}$ and HE heigth is $0.89 \mathrm{~m}$. The length of each pipe will be $2.05 \mathrm{~m}$ and $\mathrm{HE}$ height is $1.34 \mathrm{~m}$ when number of rows equal 16 .

The straight tube needed is too long or too large compare to the available space. Therefore, some fins will be added to the outer of straight pipes and $\mathrm{HE}$ becomes more compact. Heat transfer from the coolant inside tubes will be higher when there are fins added to the tubes. Thus, the length of tubes needed will be shorter. The schematic of the finned pipe is shown in Fig. 4.

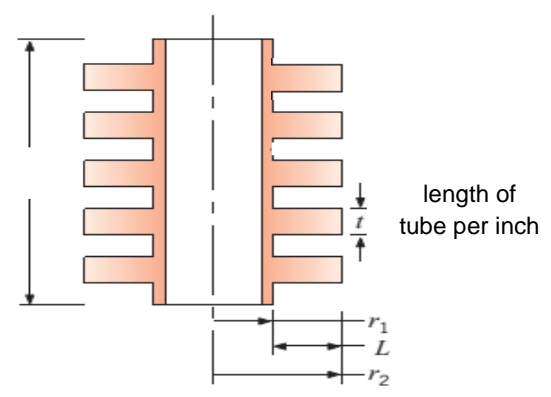

Figure 4. Finned tube length per inch scheme

Number of fins added to tubes is 5 fins per inch. The nominal size of straight tubes is $5 / 8$ ". The outer diameter is $3 / 4$ ". Fin is made of copper with 0.02 -inch thickness and 0.5 -inch length. There are five fins per inch length of tube. Because the heat transfer increases with finned tubes, the main flow is divided into 4 tubes equally. Likewise for straight tubes, the calculation was conducted several times to get some alternatives of heat exchanger with finned tubes. The result is in Fig. 5. The trend shown in Fig. 3 is exactly the same with Fig. 5. But, number of rows is clearly less for finned tubes than straight tubes. It is more compact, because the heat transfer area of finned tubes needed is less than straight tubes. More number of passes (rows) means more bending process of tubes. Thus, it is more favourable to have less number of rows (passes).

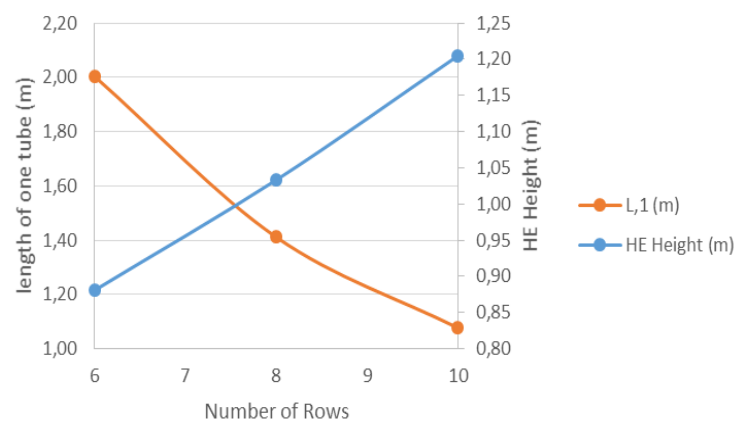

Figure 5. Some alternatives of heat exchanger with finned tubes

To determine number of rows (passes), the overall heat transfer coefficient inside HE will be compared. From calculation conducted, the overall heat transfer coefficient are found as in Table 1. The highest overall coefficient will be choosed, because it will give the highest heat transfer from coolant (flows inside finned tubes) to chilled water (inside shell, outside tubes). The highest overall heat transfer coefficient is $1265.93 \mathrm{~W} / \mathrm{m}^{2} . \mathrm{K}$ when there are 10 rows finned tube in HE. From Fig. 5, this design is adequate with available space. Thus, it is recommended that number of passes (rows) for this heat exchanger is 10 rows of finned tubes.

Table 1. Comparison of the overall heat transfer coefficient, $\mathrm{U}_{\mathrm{h}}$, with Number of Rows Alternative

\begin{tabular}{|c|c|}
\hline $\begin{array}{c}\text { Number of } \\
\text { rows }\end{array}$ & $\begin{array}{c}\text { Overall heat transfer coefficient, } \\
\mathrm{U}_{\mathrm{h}}\left(\mathrm{W} / \mathrm{m}^{2} \cdot \mathrm{K}\right)\end{array}$ \\
\hline 6 & 1133,91 \\
\hline 8 & 1207,41 \\
\hline 10 & 1265,93 \\
\hline
\end{tabular}

After design the configuration of the HE, next step is to determine its cover or shell. The shell is made of stainless steel. To prevent heat coming from ambient air to the chilled water, some glass wool will be added outside the shell. From the calculation, it is required that the thickness of glass wool is $11 \mathrm{~mm}$. The design of HE is shown in figure 6.

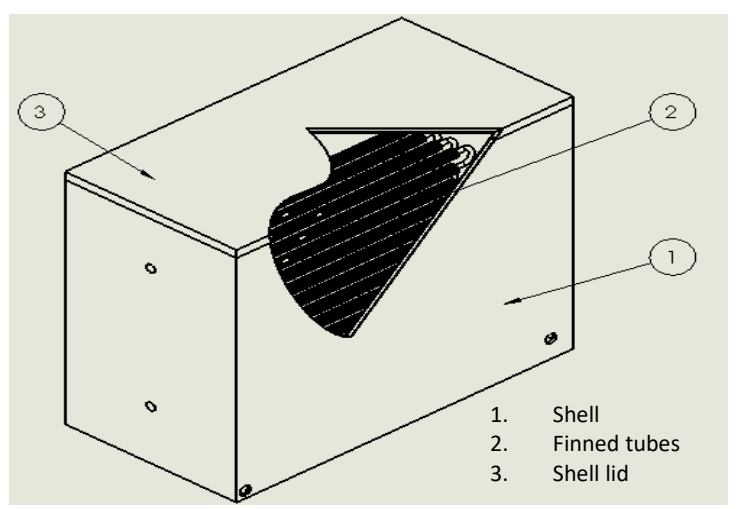

Figure 6. Heat exchanger design result 


\section{Numerical Study and Flow Analysis}

Numerical simulation is conducted using commercial software package, i.e. Fluent. Meshing needs to be designed before doing numerical simulation. The domain of numerical study is coolant that flows inside tubes. From the numerical simulation, some variables are resulted, such as outlet temperature of the coolant flowing inside tubes, its pressure drop across the HE, and its velocity vector. The coolant flow is divided in four branches and they are identical. Thus, the numerical study is conducted in one branch only.

The numerical study is conducted in 3-dimension, using double precision, second order solution scheme, and using Shear Stress Transport K- $\omega$ (SSTk $\omega)$ viscous model. The boundary setting are inlet velocity $=0.435 \mathrm{~m} / \mathrm{s}$; inlet temperature $=313 \mathrm{~K}\left(40^{\circ} \mathrm{C}\right)$; average outside tube temperature $=282.5 \mathrm{~K}\left(9.5^{\circ} \mathrm{C}\right)$ with convection heat transfer coefficient $=2660$ $\mathrm{W} / \mathrm{m} . \mathrm{K}$; tube material is copper with thickness 1.042 $\mathrm{mm}$; and the fluid is water.

After 173 iteration, the simulation is convergent. The result of numerical study is shown in Fig. 7 a) for temperature, $7 \mathrm{~b}$ ) for velocity vector, and 7 c) for pressure drop. The outlet temperature resulted from numerical study is $287.76 \mathrm{~K}\left(14,76^{\circ} \mathrm{C}\right)$. This result is very good because close enough with design temperature $288 \mathrm{~K}\left(15^{\circ} \mathrm{C}\right)$.

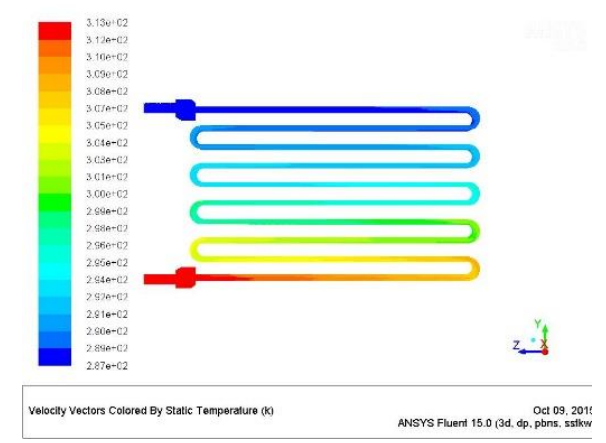

a) Temperature of fluid inside tube

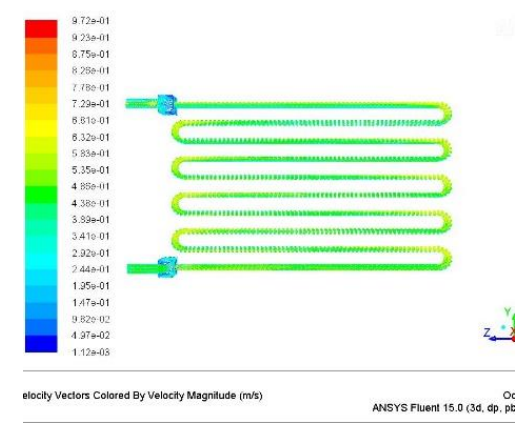

b) velocity vector of fluid inside tube

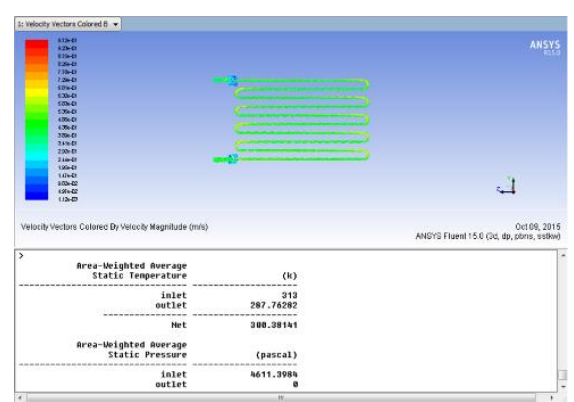

c) pressure drop of fluid across the tube

Figure 7. Result of numerical simulation of fluid inside tube

From Fig. 7 c), the static pressure drop of fluid flowing inside the tube that is calculated by Fluent is 4611.4 Pa. While doing calculation using equations or analytically, pressure drop is $5143.17 \mathrm{~Pa}$. The number is just slightly different. There are small difference number between simulation and manual calculation. The difference might be because of assumption in choosing some model, such as inlet and exit pipe model. Doing calculation manually, the biggest coefficient were chosen. This might make the pressure drop calculated manually larger.

Velocity vector of flow inside a tube around a bend is interesting to see. Fig. 8 a) shows this vector. The flow vector has no vortex in it, but some vector lines cross each other and increase pressure drop as the coolant flow across the return bend. The flow vector in straight tube is very different compare to that, as shown in Fig. 8 b). This condition conform to pressure drop or head loss that is given in fluid mechanics books. If pressure drop is calculated using basic equations [5], the minor head loss of one return bend which flow velocitity is $0.435 \mathrm{~m} / \mathrm{s}$ will be $141.6 \mathrm{~Pa}$. While the major head loss of flow with the same velocity inside the straight tube which length equals to one return bend will be $4.9 \mathrm{~Pa}$. The head loss of flow in straight tube is much lower than the return bend.

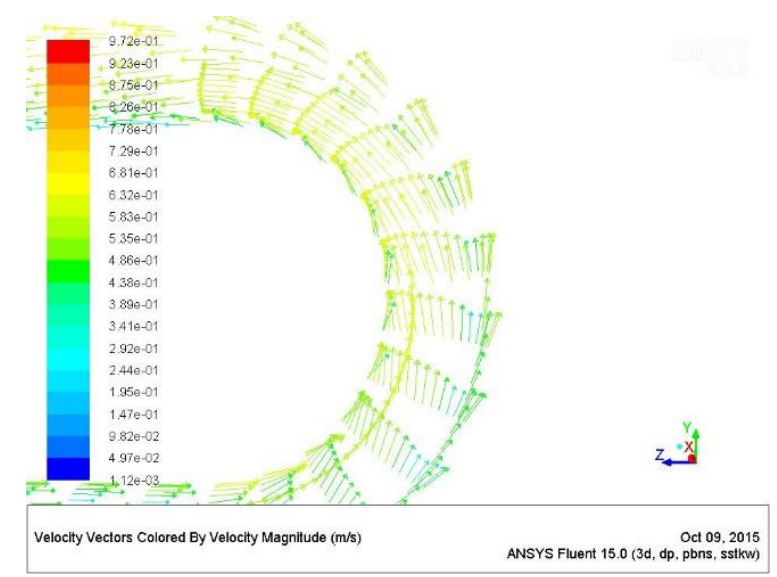




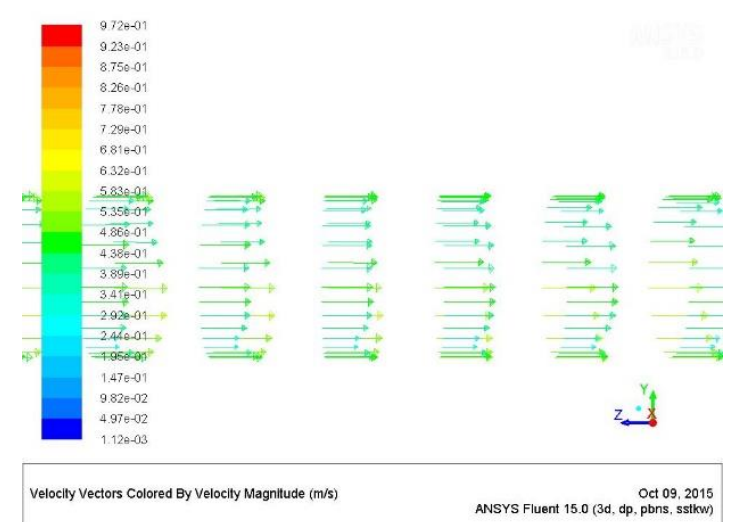

Figure 8. Velocity vector around bend inside tube

Besides flow around return bend, flow in entrance and exit are also interesting. Fig. 9 shows velocity vector of flow entering a tube from a header. There are a lot of vortex in the flow. Sudden contraction or expansion in flow is classified as minor head loss. Minor head loss at entrance and exit pipe from header make high pressure drop of the flow.

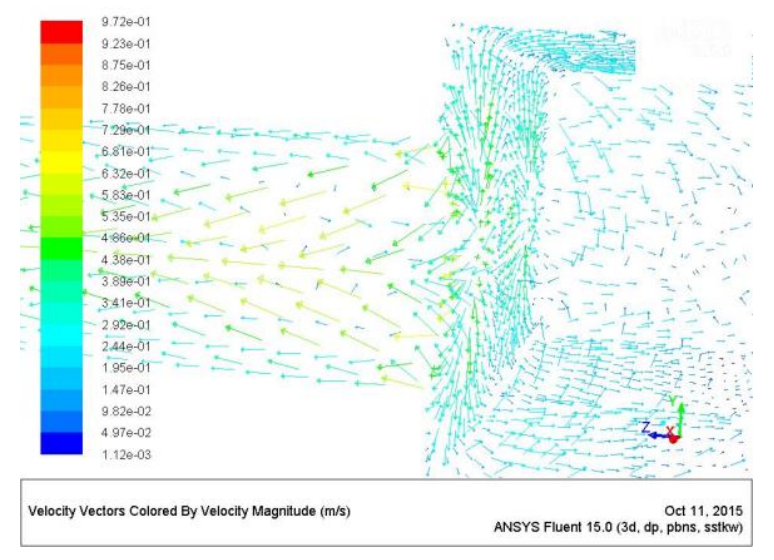

Figure 9. Velocity vector of flow entering a tube and exit from a header

\section{Kesimpulan}

A heat exchanger is designed to cool the cooling fluid of impeder from $40^{\circ} \mathrm{C}$ to $15^{\circ} \mathrm{C}$. The flow rate of coolant is $30 \mathrm{~L} / \mathrm{min}$. Chiller type UWAP750AY3 is used to produce chilled water needed by heat exchanger. The 5/8-inch-finned-copper pipes are used as tubes in the heat exchanger. The coolant is divided in four equally tubes from a header. To meet the heat transfer area needed, each tubes will be bent to make 10 passes (or rows). At the end of the last pass, four flow will be gathered in a header. Then, the coolant will circulate to impeder.

Numerical simulation was conducted to get the velocity vector and temperature distribution of flow inside the tube, and also the pressure drop of the flow across the tubes and header. Velocity vector of flow around return bend, flow in entrance and exit are interesting. They give understanding that the pressure drop will be higher in such accessories than in straight pipe. The pressure drop of coolant flowing inside tubes of heat exchanger is 5143.2 Pa from analytical solutions and $4611.4 \mathrm{~Pa}$ from numerical simulation using Fluent. Temperature of coolant at outlet got from numerical simulation is almost the same with the designed temperature, i.e. $15^{\circ} \mathrm{C}$. So, the numerical simulation reinforces the design of the heat exchanger.

\section{Daftar Pustaka}

[1] Walravena, D., Laenen, B., \& D'haeseleer, W. (2014). Comparison of shell-and-tube with plate heat exchangers for the use in low-temperature organic Rankine cycles. Energy Conversion and Management, 227 - 237.

[2] McGeorge, H. (2014). General Engineering Knowledge, Heat Exchanger. Marine Engineering Study Materials.

[3] Incropera, F. P., \& DeWitt, D. P. (2002). Fundamentals of Heat and Mass Transfer. 5th edition ed. s.1.:. John Wiley \& Sons.

[4] Daikin. (2016). Daikin Water Chillers Catalogue (PCU0610A).

[5] Cengel, Y., \& Boles, M. (2005). Thermodynamics: An Engineering Approach, 5th ed. McGraw-Hill.

[6] Cengel, Y. A. (2006). Fluid Mechanics: Fundamentals and Application. New York: McGraw-Hill. 